\title{
Effect of Organic and Mineral Nitrogenous \\ Fertilizers and Plant Density on Yield and Quality of Sugar Beet (Beta vulgaris L.)
}

\author{
E. A. Mahmoud, M. A. Hassanin and Eman I. R. Emara \\ Agronomy Department, Faculty of Agriculture, Cairo \\ University, Cairo, Egypt.
}

TWO FIELD trials were conducted during 2008/2009 and 2009/2010 seasons in the Agricultural experiment and Research Center, Fac. Agric., Cairo Univ., Giza, Egypt, to study the response of sugar beet to mineral $\mathrm{N}$ rates $\left(60,80\right.$ and $\left.100 \mathrm{~kg} / \mathrm{fed}^{1}\right)$, compost rates $(0,1$ and 2 tons/fed of plant compost $15 \% \mathrm{~N})$ and plant density $(40 \mathrm{x}$ $10^{3}$ and $46 \times 10^{3}$ plants/fed). Results revealed that increasing $\mathrm{N}$ rate up to $100 \mathrm{~kg}$ significantly favored beet growth in terms of leaf area index (LAI) at 145 and 175 days from sowing as well as relative growth rate (RGR) and individual root weight. LAI decreased as plants advanced towards maturity. On the other hand, juice quality traits, sucrose, purity and sugar recovery were decreased as $\mathrm{N}$ rate increased, while sucrose loss to molasses was gradually increased as $\mathrm{N}$ rate increased. A substantial increase in root yield $(24.9 \%$ and $21.5 \%)$ and recoverable sugar yield $(16.7 \%$ and $11.3 \%)$ was recorded as $\mathrm{N}$ rate increased from 60 to $100 \mathrm{~kg} / \mathrm{fed}$ in the first and second season, respectively .

Application of 2 tons of compost/fed significantly produced the highest LAI and RGR as well as the heaviest roots, and improved juice quality traits (sucrose, purity and recoverable sugar \%). 1 and 2 tons of compost were significantly different in most of quality traits. Increasing compost rate from zero to 2 tons/fed increased root yield by 16.4 and $14.0 \%$ and sugar yield by 27.8 and $20.2 \%$ in the first and second seasons, respectively.

Increasing plant density from 40000 to 46000 plants/fed depressed beet growth in terms of LAI, RGR and root fresh weight, while sucrose, purity and recoverable sugar $\%$ were increased with increasing plant density. On the other hand, sucrose loss to molasses decreased as plant density increased. 46000 plants maximized root and sugar production per feddan. All interactions between the studied factors were significant with respect to the studied traits in both seasons. The highest root yield 41.57 and 41.02 ton/fed and sugar yield 6.30 and 5.87 ton/fed resulted from $100 \mathrm{~kg} \mathrm{~N}+2$ tons of compost with 46000 plants/fed .

Keywords: Sugar beet, Organic nitrogen, Mineral nitrogen, Plant density and quality. 
Nitrogen is the essential mineral element for sugar beet growth by the greatest influencing on root quality and sugar production. In Egypt, sugar beet growers intend to apply excess nitrogen in beet fields believing that high vegetative growth of beet plants must be reflecting on absolute high root yield. Widely ranging optimum rates of nitrogen have been reported in the literature. Strand \& Vales (1987) recommended $120 \mathrm{~kg} / \mathrm{ha}$. Halverson \& Hartman (1988) found that $150 \mathrm{~kg} / \mathrm{ha}$ was the economic rate for maximum root production. Imura \& Hayassaka (1987) found that raising $\mathrm{N}$ rates up to $200 \mathrm{~kg} / \mathrm{ha}$ increased root and sugar yield. Halverson \& Hartman (1980) reported optimum rates as high as $390 \mathrm{~kg} / \mathrm{ha}$. In Egypt some researchers found that root yield significantly increased with rates up to $80 \mathrm{~kg} / \mathrm{fed} \mathrm{(Mahmoud} \mathrm{et} \mathrm{al.,} 1990$ and Salama \& Badawi, 1996). Others recommended $90 \mathrm{~kg} /$ fed for maximum root and sugar yield (El-Shafai, 2000), while Abd El-Aal et al. (2007) found that $100 \mathrm{~kg} / \mathrm{fed}$ maximized yield productivity. El-Hennawy et al. (1998) recommended optimum rate as high as $120 \mathrm{~kg} / \mathrm{fed}$. Some workers have reported that higher nitrogen rates favored beet growth in terms of leaf area/plant, LAI, RGR and fresh and dry weight of the root (Mahmoud et al., 1990; Besheit et al., 1995 and Abd El-Aal et al., 2007).

Some investigators found that sugar beets grown with inadequate $\mathrm{N}$ generally have a high sucrose percentage and low impurities (sodium, potassium and alpha amino $\mathrm{N}$ ) but root and sucrose production was limited. Too much $\mathrm{N}$ dose increases root impurities and reduces sucrose percentage and consequently limits refined sucrose production (Carter \& Traveller, 1981 and Ramadan, 1997).

The influence of soil fertilization on nutrient content in crops has been studied and different results have been recorded. Some authors show that the application of organic amendment improves soil nutrient content, but does not always increases plant nutrient concentration (Maareg et al., 2008 and Kadar et al., 2009). Nassar et al. (2000) found that raising farmyard manure rates from zero to $50 \mathrm{~m}^{3} /$ fed caused gradual increases of most growth traits, i.e. root length, root diameter, leaf area/plant, top/root ratio, root and top fresh weight/plant and root and sugar yields. El-Geddawy et al. (2003) and Kadar et al. (2009) found that adding farmyard manure increased the values of root fresh weight/plant as well as percentage of dry matter, sucrose percentage and root and sugar yields. Mohamed (2008) found that application of 2 tons of compost/fed to sugar beet increased size, fresh and dry weight of the roots as well as sucrose $\%$ and sugar yield compared to mineral $\mathrm{N}$.

Plant density has a pronounced effect on beet productivity. Some workers reported that sucrose and purity percentages decreased linearly as population density decreased. On the other hand, increasing plant density reduced impurities in beet juice (Eckhoff et al., 1991). Lauer (1995) reported that the highest sugar yield resulted from 70 to 100 thousand plants/ha. In Egypt the optimum plant density that could maximize sugar beet yield has received attention of some workers. Ramadan (1999) and Nassar (2001) found that sucrose, purity and recoverable sugar percentages were linearly reduced with the reduction in plant density, while root fresh weight, LAI, plant dry weight, $\mathrm{Na}, \mathrm{K}$, amino-N content

Egypt. J. Agron . 34, No.1 (2012) 
and sucrose loss to molasses percentage were decreased with increasing plant density. Allam et al. (2005) reported that $25 \mathrm{~cm}$ surpassed $15 \mathrm{~cm}$ plant spacing in leaves dry weight, leaf area/plant, total soluble solids as well as top, root and sugar yields.

\section{Materials and Methods}

Two field experiments were carried out at Agricultural Experiment and Research Center of the faculty of Agriculture, Cairo University, Giza, Egypt during 2008 / 2009 and 2009 / 2010 seasons, to study the effect of mineral and organic nitrogen manures on growth, yield and quality of sugar beet under two plant densities. The variety used was Monte Bianko (from Germany) which was obtained by the Sugar Crops Research Institute, Agriculture Research Center, Egypt. Chemical analysis of the two experimental soils are presented in Table 1.

TABLE 1. Chemical analysis of the soil in 2008 and 2009 seasons.

\begin{tabular}{|l|c|c|}
\hline Analysis & $\mathbf{1}^{\text {st }}$ season & $\mathbf{2}^{\text {nd }}$ season \\
\hline Available N kg/fed & 20.3 & 26.3 \\
Available P (ppm) & 1895 & 1987 \\
Available K (ppm) & 3200 & 3300 \\
Organic matter (\%) & 1.7 & 1.9 \\
pH & 7.3 & 7.4 \\
EC & 0.9 & 0.8 \\
\hline
\end{tabular}

\section{Treatments}

(1) Three nitrogen rates were used in the form of ammonium nitrates $(33 \% \mathrm{~N})$, i.e. 60,80 and $100 \mathrm{~kg} \mathrm{~N} /$ feddan. Nitrogen rates were divided into two equal doses, the first was applied after thinning (45 days from sowing) the second was applied 4 weeks later.

(2) Organic fertilizer (Plant compost): Three organic fertilizer rates (Zero, 1 and 2 tons/fed) were used in the form of compost (Nile Compost) which was added to the soil two weeks before planting. The analysis of the compost is shown in Table 2.

(3) Plant densities: Two plant densities 40000 and 46000 plants/feddan resulted from planting on 17.5 and $15 \mathrm{~cm}$ between hills and $60 \mathrm{~cm}$ between rows. The preceding crop was corn in both seasons.

A split-split plot design with four replicates was used, nitrogen rates were arranged randomly in the main plots, compost rates in the sub plots and plant densities in the sub sub plots, the sub sub plot area was $15 \mathrm{~m}^{2}$ and consisted of five ridges of $5 \mathrm{~m}$ in length and $60 \mathrm{~cm}$ apart. Sowing was on $19^{\text {th }}$ and $13^{\text {th }}$ of October in 2008/2009 and 2009/2010 seasons, respectively, and the field was irrigated immediately after planting. Seedlings were thinned at 4-6 leaf stage to ensure one plant per hill. Phosphorus fertilizer at a rate of $30 \mathrm{~kg} \mathrm{P}_{2} \mathrm{O}_{5} / \mathrm{fed}$ in the 
form of superphosphate $\left(15.5 \% \mathrm{P}_{2} \mathrm{O}_{5}\right)$ was added at sowing in both seasons. Potassium fertilizer at a rate of $48 \mathrm{~kg} \mathrm{~K}_{2} \mathrm{O} / \mathrm{fed}$ in the form of Potassium Sulphate $\left(48 \% \mathrm{~K}_{2} \mathrm{O}\right)$ was added with the first dose of Nitrogen. Other cultural practices were carried out as usual. Harvest of sugar beet plants took place after 200 days from sowing in both seasons of experimentation.

TABLE 2. Some physical and chemical properties of the compost.

\begin{tabular}{|l|c|}
\hline Character & Component \\
\hline Weight of $1 \mathrm{~m}^{3}(\mathrm{kgm})$ & 625 \\
Humidity percentage $(\%)$ & 30 \\
pH (extractable 1:5) & 7.8 \\
Ec(extractable 1:5) (mmol/com) & 2.75 \\
Total nitrogen \% & 15 \\
Amonouim nitrogen $(\mathrm{ppm})$ & 160 \\
Nitrate nitrogen (ppm) & 125 \\
Organic matter $(\%)$ & 50 \\
Organic carbon $(\%)$ & 29 \\
C/N ratio & 17.5 \\
Nacl (5) & 1.21 \\
Dobalic acids $(\%)$ & 13 \\
Total phosphorus $(\%)$ & 0.7 \\
Total potassium $(\%)$ & 1.25 \\
Fe (ppm) & 1587 \\
Mn (ppm) & 162 \\
Cu $(\mathrm{ppm})$ & 65 \\
Zn (ppm) & 21 \\
\hline
\end{tabular}

\section{Studied characters}

Growth characters

1) Root, blades, petioles and plant dry weight were determined using a sample of 5 plants from each plot after drying in an oven at $70^{\circ} \mathrm{C}$ till constant weight.

2) Leaf area index (LAT), relative growth rate (RGR) and net assimilation rate (NAR) were determined according to Watson (1958).

\section{Juice quality characters}

At harvest a random sample of 10 plants from each sub plot was taken and the following traits were determined at Delta Sugar Company, Kafrelsheikh, Egypt.

1) Sucrose percentage was determined polarimeterically .

2) Impurities percentage $=[(\mathrm{K}+\mathrm{Na}) \times 0.343)+($ alpha amino $\mathrm{N} \times 0.094+0.29)]$ where: K, Na and a-amino $\mathrm{N}$ (meq/100g sugar beet).

3) Purity percentage $=[(($ sucrose $\%$ - impurities \%) $\times 100) /$ sucrose \% $]$

4) Recoverable sugar percentage (R.S \%) was determined by using the following formula:

RS \% $=[\mathrm{Pol} \%-0.029-0.343(\mathrm{Na}+\mathrm{K})-0.094($ alpha amion $\mathrm{N})]$ 
5) Sucrose loss to molasses (SLM) =

$[0.343(\mathrm{Na}+\mathrm{K})+0.094($ alpha amino $\mathrm{N})-0.31]$

Yield and its components

Yields were determined from the middle three rows of each plot.

1) Number of plants at harvest

2) Root fresh weight/ plant

3) Root yield

4) Recoverable sugar yield (RSY) $=$ Root yield (ton/fed)* Recoverable sugar $\%$.

Statistical analysis

Data collected were subjected to the proper statistical analysis of variance of split-split plot design according to the procedures outlined by Snedecor \& Cochran (1967) to compare treatment means; L.S.D. at 5\% level of significance was used according to Steel \& Torrie (1980). All statistical analysis was performed by using analysis of variance technique of (MSTAT) Computer software package.

\section{Results and Discussion}

\section{Effect of nitrogen fertilizer}

Growth traits

Data presented in Table 3 revealed that LAI, RGR and root fresh weight were significantly and gradually increased as $\mathrm{N}$ rate increased up to $100 \mathrm{~kg} / \mathrm{fed}$. LAI increased by 29.9 and $22.9 \%$ after 145 days and 19.7 and $29.2 \%$ after 175 days from sowing. RGR increased by 24.6 and $34.6 \%$ and root fresh weight by 15.5 and $12.1 \%$ as $\mathrm{N}$ rate increased from 60 to $100 \mathrm{~kg} / \mathrm{fed}$ in the first and second seasons, respectively. Such obtained results insure the important role of nitrogen in stimulating and enhancing the photosynthetic and metabolic actives of plants which were reflected on the increase in the vegetative growth of beet plants. It is worth to mention that LAI decreased as plants advanced toward maturity as a result of leaf senescence. These results are in harmony with those of Mahmoud et al. (1990) Besheit et al. (1995) and Abd El-Aal et al. (2007).

\section{Quality traits}

Quality traits in terms of percentages of sucrose, purity, sugar recovery and sucrose loss to molasses were significantly affected by nitrogen application in both seasons (Table 4). The increase in $\mathrm{N}$ rate from 60 to $100 \mathrm{~kg} /$ fed gradually depressed sucrose, purity and sugar recovery $\%$. The highest reduction resulted from the first increment $(60-80 \mathrm{~kg} / \mathrm{fed})$. On the other hand, sucrose lose to molasses was gradually increased as $\mathrm{N}$ rate increased. Such effect might have been due to reduction in sucrose and sugar recovery accompanying high nitrogen rates. The depressive effect of high $\mathrm{N}$ rate on beet quality has been reported by Carter \& Traveller (1981) and Abd El-Aal et al. (2007). 
TABLE 3. Effect of mineral nitrogen on some growth traits of sugar beet plants.

\begin{tabular}{|c|c|c|c|c|}
\hline \multirow{3}{*}{ N kg/fed } & \multicolumn{4}{|c|}{ Leaf area index (LAI) } \\
\hline & \multicolumn{2}{|c|}{$1^{\text {st }}$ season } & \multicolumn{2}{|c|}{$2^{\text {nd }}$ season } \\
\hline & 145 days & 175 days & 145 days & 175 days \\
\hline 60 & 4.25 & 3.41 & 4.02 & 3.08 \\
\hline 80 & 5.11 & 3.83 & 4.50 & 3.48 \\
\hline 100 & 5.52 & 4.19 & 4.81 & 3.89 \\
\hline L.S.D ${ }_{5 \%}$ & 0.84 & 0.77 & 0.52 & 0.67 \\
\hline \multirow{2}{*}{ N kg/fed } & \multicolumn{2}{|c|}{ RGR 145-175 days (g/g/week) } & \multicolumn{2}{|c|}{ Root fresh weight (g) } \\
\hline & $1^{s t}$ season & $2^{\text {nd }}$ season & $1^{s t}$ season & $2^{n d}$ season \\
\hline 60 & 0.134 & 0.130 & 1068 & 1104 \\
\hline 80 & 0.147 & 0.153 & 1180 & 1148 \\
\hline 100 & 0.167 & 0.175 & 1234 & 1238 \\
\hline L.S.D ${ }_{5 \%}$ & 0.014 & 0.014 & 78 & 98 \\
\hline
\end{tabular}

TABLE 4. Effect of mineral nitrogen on juice quality traits of sugar beet plants.

\begin{tabular}{|l|c|c|c|c|}
\hline \multirow{2}{*}{ N kg/fed } & \multicolumn{2}{|c|}{ Sucrose (\%) } & \multicolumn{2}{c|}{ Purity (\%) } \\
\cline { 2 - 5 } & $\mathbf{1}^{\text {st }}$ season & $\mathbf{2}^{\text {nd }}$ season & $\mathbf{1}^{\text {st }}$ season & $\mathbf{2}^{\text {nd }}$ season \\
\hline 60 & 17.02 & 18.32 & 87.40 & 83.42 \\
80 & 16.61 & 17.20 & 84.35 & 82.32 \\
100 & 16.49 & 16.48 & 83.95 & 82.01 \\
\hline L.S.D & 0.38 & 0.45 & 0.69 & 0.64 \\
\hline \multirow{2}{*}{ N kg/fed } & \multicolumn{2}{|c|}{ Sugar recovery (\%) } & \multicolumn{2}{c|}{ Sucrose loss (\%) } \\
\cline { 2 - 6 } & $\mathbf{1}^{\text {st }}$ season & $\mathbf{2}^{\text {nd }}$ season & $\mathbf{1}^{\text {st }}$ season & $\mathbf{2}^{\text {nd }}$ season \\
\hline 60 & 15.34 & 15.28 & 1.49 & 2.03 \\
80 & 14.49 & 14.42 & 1.68 & 2.18 \\
100 & 14.34 & 14.01 & 1.71 & 2.31 \\
\hline L.S.D & 0.39 & 0.24 & 0.04 & 0.03 \\
\hline
\end{tabular}

Root and recoverable sugar yields

Nitrogen exhibited significant effect on root and sugar yield in both seasons (Table 5). Increasing $\mathrm{N}$ rate from 60 to $80 \mathrm{~kg} /$ fed increased root yield by 11.1 and $7.2 \%$ and recoverable sugar yield by 4.9 and $2.7 \%$, respectively. Whereas Egypt. J. Agron. 34, No.1 (2012) 
increasing $\mathrm{N}$ rate from 80 to $100 \mathrm{~kg} / \mathrm{fed}$ increased root yield by 12.5 and $11.7 \%$ and recoverable sugar yield by 11.2 and $8.4 \%$ in the first and second seasons as compared to control treatment, respectively. It is worth to mention that the reduction in sucrose and sugar recovery was compensated by the increase in root yield and finally sugar yield increased. Similar results insuring the role of $\mathrm{N}$ in increasing root and sugar production were reported by Halverson \& Hartman (1988), El-Hennawy et al. (1998) and El-Shafai (2000).

TABLE 5. Effect of mineral nitrogen fertilizer on yields of root and recoverable sugar of sugar beet plants.

\begin{tabular}{|l|c|c|c|c|}
\hline \multirow{2}{*}{ N kg/fed } & \multicolumn{2}{|c|}{ Root yield (ton/fed) } & \multicolumn{2}{c|}{ Recoverable sugar yield (ton/fed) } \\
\cline { 2 - 5 } & $\mathbf{1}^{\text {st }}$ season & $\mathbf{2}^{\text {nd }}$ season & $\mathbf{1}^{\text {st }}$ season & $\mathbf{2}^{\text {nd }}$ season \\
\hline 60 & 30.37 & 31.14 & 4.66 & 4.76 \\
80 & 33.73 & 33.88 & 4.89 & 4.89 \\
100 & 37.94 & 37.85 & 5.44 & 5.30 \\
\hline L.S.D $5 \%$ & 1.63 & 2.07 & 0.28 & 0.30 \\
\hline
\end{tabular}

Effect of compost fertilizer

Growth traits

Data presented in Table 6 revealed that compost application favored beet growth. Significant differences between compost rates were recorded in LAI at 145 and 175 days after sowing, as well as RGR and root fresh weight in both seasons.

TABLE 6. Effect of compost application on some growth traits of sugar beet plants.

\begin{tabular}{|c|c|c|c|c|}
\hline \multirow{3}{*}{$\begin{array}{l}\text { Comp. } \\
\text { ton/fed }\end{array}$} & \multicolumn{4}{|c|}{ Leaf area index (LAI) } \\
\hline & \multicolumn{2}{|c|}{$1^{s t}$ season } & \multicolumn{2}{|c|}{$2^{\text {nd }}$ season } \\
\hline & 145 days & 175 days & 145 days & 175 days \\
\hline 0 & 4.32 & 3.17 & 3.90 & 2.86 \\
\hline 1 & 4.97 & 3.75 & 4.54 & 3.42 \\
\hline 2 & 5.59 & 4.51 & 4.89 & 4.16 \\
\hline L.S.D ${ }_{5 \%}$ & 0.84 & 0.77 & 0.52 & 0.67 \\
\hline \multirow{2}{*}{$\begin{array}{l}\text { Comp. } \\
\text { ton/fed }\end{array}$} & \multicolumn{2}{|c|}{ RGR $145-175$ days (g/g/week) } & \multicolumn{2}{|c|}{ Root fresh weight (g/plant) } \\
\hline & $1^{\text {st }}$ season & $2^{n d}$ season & $1^{s t}$ season & $2^{n d}$ season \\
\hline 0 & 0.134 & 0.550 & 1125 & 1103 \\
\hline 1 & 0.148 & 0.650 & 1162 & 1171 \\
\hline 2 & 0.166 & 0.700 & 1207 & 1207 \\
\hline L.S.D ${ }_{5 \%}$ & 0.014 & 0.014 & 78 & 98 \\
\hline
\end{tabular}

Egypt. J. Agron . 34, No.1 (2012) 
Application of 2 tons of compost produced the highest LAI and RGR as well as the heaviest roots. Reflecting the important role of organic manure on releasing up most of essential elements for beet growth. Some authors show that the application of organic amendment improves soil nutrient content (Maareg et al., 2008). In this connection, Nassar et al. (2000) and El-Geddawy et al. (2003) found that farmyard manure increased most of growth traits of sugar beet, i.e. root, top fresh, dry weight and leaf area/plant.

\section{Quality traits}

Data in Table 7 revealed a significant effect of compost application on juice quality traits in terms of sucrose, purity, sugar recovery in both seasons and sucrose loss to molasses only in the second season. These traits gradually increased as compost rate increased from zero to 2 tons/fed. A significant difference between 1 and 2 tons of compost/fed was recorded in most of quality traits. Such effect of compost might have been due to improving soil nutrient release and content in particular potassium which has an important role in moving and translocation of carbohydrates from tops to roots.

TABLE 7. Effect of compost application on juice quality traits of sugar beet plants.

\begin{tabular}{|l|c|c|c|c|}
\hline \multirow{2}{*}{$\begin{array}{l}\text { Comp. } \\
\text { ton/fed }\end{array}$} & \multicolumn{2}{|c|}{ Sucrose (\%) } & \multicolumn{2}{c|}{ Purity (\%) } \\
\cline { 2 - 5 } & $\mathbf{1}^{\text {st }}$ season & $\mathbf{2}^{\text {nd }}$ season & $\mathbf{1}^{\text {st }}$ season & $\mathbf{2}^{\text {nd }}$ season \\
\hline 0 & 15.84 & 16.18 & 84.15 & 81.75 \\
1 & 16.62 & 16.61 & 85.42 & 82.69 \\
2 & 17.03 & 16.67 & 86.12 & 83.30 \\
\hline L.S.D 5\% & 0.38 & 0.45 & 0.69 & 0.64 \\
\hline \multirow{2}{*}{ Comp. } & \multicolumn{2}{|c|}{ Sugar recovery (\%) } & \multicolumn{2}{c|}{ Sucrose loss (\%) } \\
\cline { 2 - 5 } ton/fed & $\mathbf{1}^{\text {st }}$ season & $\mathbf{2}^{\text {nd }}$ season & $\mathbf{1}^{\text {st }}$ season & $\mathbf{2}^{\text {nd }}$ season \\
\hline 0 & 13.99 & 14.21 & 1.65 & 2.17 \\
1 & 14.82 & 14.54 & 1.62 & 2.19 \\
2 & 15.36 & 14.97 & 1.62 & 2.16 \\
\hline L.S.D & 0.39 & 0.24 & Ns & 0.03 \\
\hline
\end{tabular}

These results are in harmony with those obtained by El-Geddawy et al. (2003) and Montemurro et al. (2007) who found that mixed organic and mineral $\mathrm{N}$ increased sucrose $\%$ and reduced alpha amino $\mathrm{N}$ in beet roots by $13.2 \%$ as compared with mineral $\mathrm{N}$ of $100 \mathrm{~kg} / \mathrm{ha}$.

Root and recoverable sugar yields

Differences among compost application in root and recoverable sugar yields were significant in both seasons (Table 8). Increasing compost rate from zero to

Egypt. J. Agron . 34, No.1 (2012) 
2 tons/fed resulted in a substantial increase in root and sugar production. The increase amounted to 16.4 and $14.0 \%$ for root yield and 27.8 and $20.2 \%$ for sugar yield in the first and second seasons, respectively reflecting the better growth traits in terms of LAI, RGR and root weight as well as the increase in quality traits accompanying compost application. Such results match with those of Nassar et al. (2000), El-Geddawy et al. (2003) and Kadar et al. (2009).

TABLE 8. Effect of compost application on yields of sugar beet plants.

\begin{tabular}{|l|c|c|c|c|}
\hline \multirow{2}{*}{$\begin{array}{l}\text { Comp. } \\
\text { ton/fed }\end{array}$} & \multicolumn{2}{|c|}{ Root yield (ton/fed) } & \multicolumn{2}{c|}{ Recoverable sugar yield (ton/fed) } \\
\cline { 2 - 5 } & $\mathbf{1}^{\text {st }}$ season & $\mathbf{2}^{\text {nd }}$ season & $\mathbf{1}^{\text {st }}$ season & $\mathbf{2}^{\text {nd }}$ season \\
\hline 0 & 31.85 & 32.04 & 4.46 & 4.55 \\
1 & 33.11 & 34.31 & 4.91 & 4.99 \\
2 & 37.08 & 36.52 & 5.70 & 5.47 \\
\hline L.S.D $5 \%$ & 1.63 & 2.07 & 0.28 & 0.30 \\
\hline
\end{tabular}

Effect of plant density

Growth traits

Data presented in Table 9 revealed that increasing plant density from 40000 to 46000 plants/fed significantly decreased beet growth in terms of LAI, RGR and root fresh weight in both seasons. LAI decreased by 19.6 and $21.3 \%$ in the first season and by 19.7 and $27.7 \%$ in the second season after 145 and 175 days from sowing, respectively. RGR decreased by 13.8 and $17.4 \%$, while root fresh weight decreased by 3.4 and $4.1 \%$ in the first and second seasons, respectively. Such effect might have been due to interplant competition for light and mineral nutrients. Similar results were reported by Mahmoud et al. (1990), Ramadan (1999) and Nassar (2001).

TABLE 9. Effect of plant density on some growth traits of sugar beet plants.

\begin{tabular}{|c|c|c|c|c|}
\hline \multirow{3}{*}{$\begin{array}{l}\text { Pl.density } \\
\text { plant/fed }\end{array}$} & \multicolumn{4}{|c|}{ Leaf area index (LAI) } \\
\hline & \multicolumn{2}{|c|}{$1^{s t}$ season } & \multicolumn{2}{|c|}{$2^{\text {nd }}$ season } \\
\hline & 145 days & 175 days & 145 days & 175 days \\
\hline 40000 & 5.50 & 4.27 & 4.93 & 4.04 \\
\hline 46000 & 4.42 & 3.36 & 3.96 & 2.92 \\
\hline L.S.D $5 \%$ & 0.68 & 0.63 & 0.42 & 0.55 \\
\hline \multirow{2}{*}{$\begin{array}{l}\text { Pl.density } \\
\text { plant/fed }\end{array}$} & \multicolumn{2}{|c|}{ RGR 145-175 days (g/g/week) } & \multicolumn{2}{|c|}{ Root fresh weight (g) } \\
\hline & $1^{\text {st }}$ season & $2^{\text {nd }}$ season & $\mathbf{1}^{\text {st }}$ season & $2^{\text {nd }}$ season \\
\hline 40000 & 0.160 & 0.167 & 1185 & 1185 \\
\hline 46000 & 0.138 & 0.138 & 1145 & 1136 \\
\hline L.S.D $5 \%$ & 0.017 & 0.014 & 30 & 32 \\
\hline
\end{tabular}

Egypt. J. Agron . 34, No.1 (2012) 
Quality traits

A marked increase in sucrose $\%$, purity $\%$ and sugar recovery $\%$ was recorded as plant density increased up to 46000 plants/fed (Table 10). On the other hand, sucrose loss to molasses was significantly decreased as plant density increased, reflecting the reduction in root weight and the small size roots are assumed to contain more sucrose, as reported by Eckhoff et al. (1991), Lauer (1995) and Ramadan (1999).

TABLE 10. Effect of plant density on juice quality traits of sugar beet plants.

\begin{tabular}{|l|c|c|c|c|}
\hline \multirow{2}{*}{$\begin{array}{l}\text { Pl.density } \\
\text { plant/fed }\end{array}$} & \multicolumn{2}{|c|}{ Sucrose (\%) } & \multicolumn{2}{c|}{ Purity (\%) } \\
\cline { 2 - 5 } & $\mathbf{1}^{\text {st }}$ season & $\mathbf{2}^{\text {nd }}$ season & $\mathbf{1}^{\text {st }}$ season & $\mathbf{2}^{\text {nd }}$ season \\
\hline 40000 & 16.40 & 17.23 & 85.15 & 82.11 \\
46000 & 17.01 & 17.43 & 85.31 & 83.05 \\
\hline L.S.D $5 \%$ & 0.31 & 0.19 & Ns & 0.52 \\
\hline \multirow{2}{*}{$\begin{array}{l}\text { Pl.density } \\
\text { plant/fed }\end{array}$} & \multicolumn{2}{|c|}{ Sugar recovery (\%) } & \multicolumn{2}{c|}{ Sucrose loss (\%) } \\
\cline { 2 - 5 } & $\mathbf{1}^{\text {st }}$ season & $\mathbf{2}^{\text {nd }}$ season & $\mathbf{1}^{\text {st }}$ season & $\mathbf{2}^{\text {nd }}$ season \\
\hline 40000 & 14.46 & 14.40 & 1.62 & 2.23 \\
46000 & 14.99 & 14.74 & 1.64 & 2.12 \\
\hline L.S.D & 0.32 & 0.19 & Ns & \multicolumn{2}{c}{0.11} \\
\hline
\end{tabular}

Root and recoverable sugar yields

Plant density exhibited significant effect on root and sugar yield/fed (Table 11). Root yield increased by 7.6 and $5.8 \%$ and sugar yield by 11.4 and $8.3 \%$ as plant density increased up to 46000 plants/fed in the first and second season, respectively. It is worth, mentioning, that the reduction in growth traits accompanying dense sowing was compensated by the increase in plant density and finally root and recoverable sugar yields were increased. These results are in harmony with those obtained by Mahmoud et al. (1990), Lauer (1995), Ramadan (1999), Nassar (2001) and Allam et al. (2005).

TABLE 11. Effect of plant density on yields of sugar beet plants.

\begin{tabular}{|l|c|c|c|c|}
\hline \multirow{2}{*}{$\begin{array}{l}\text { Pl.density } \\
\text { plant/fed }\end{array}$} & \multicolumn{2}{|c|}{ Root yield (ton/fed) } & \multicolumn{2}{c|}{ Recoverable sugar yield (ton/fed) } \\
\cline { 2 - 5 } & $\mathbf{1}^{\text {st }}$ season & $\mathbf{2}^{\text {nd }}$ season & $\mathbf{1}^{\text {st }}$ season & $\mathbf{2}^{\text {nd }}$ season \\
\hline 40000 & 32.77 & 33.33 & 4.74 & 4.80 \\
46000 & 35.26 & 35.25 & 5.28 & 5.20 \\
\hline L.S.D $5 \%$ & 1.33 & 1.69 & 0.23 & 0.25 \\
\hline
\end{tabular}

Egypt. J. Agron . 34, No.1 (2012) 


\section{Interaction effects}

Results in Table 12 revealed that all interactions between the studied factors were significant in both seasons. The highest values of LAI 6.73 and 5.86 in the first season and 5.91 and 5.04 in the second season, as well as RGR 0.191 and 0.215 , root fresh weight 1297 and $1365(\mathrm{~g})$, sucrose $17.67 \%$ and $18.52 \%$, purity $88.31 \%$ and $84.24 \%$ resulted from $100 \mathrm{~kg} \mathrm{~N}+2$ tons of compost +40000 plants/ fed in the first and second seasons, respectively. While the highest percentages of sugar recovery $16.07 \%$ and $15.83 \%$ and sucrose loss to molasses $1.78 \%$ and $2.50 \%$ resulted from application of $60 \mathrm{~kg} \mathrm{~N}+1$ ton of compost +40000 plants / fed. The highest root yield 41.57 ton and 41.02 ton and sugar yield 6.30 ton and 5.87 ton/fed was obtained from $100 \mathrm{~kg} \mathrm{~N}+2$ tons of compost +46000 plants/fed.

TABLE 12. Highest values of the interactions between the studied factors.

\begin{tabular}{|c|c|c|c|c|}
\hline \multirow{3}{*}{ Interactions } & \multicolumn{4}{|c|}{ Leaf area index (LAI) } \\
\hline & \multicolumn{2}{|c|}{$\mathbf{1}^{\text {st }}$ season } & \multicolumn{2}{|c|}{$2^{n d}$ season } \\
\hline & 145 days & 175 days & 145 days & 175 days \\
\hline $\mathrm{N} \times \mathrm{C}$ & $6.10\left(\mathrm{~N}_{3} \times \mathrm{C}_{3}\right)^{*}$ & $5.16\left(\mathrm{~N}_{3} \times \mathrm{C}_{3}\right)^{*}$ & $5.41\left(\mathrm{~N}_{3} \times \mathrm{C}_{3}\right)^{*}$ & $4.45\left(\mathrm{~N}_{3} \times \mathrm{C}_{3}\right)^{*}$ \\
\hline $\mathrm{N} \times \mathrm{P}$ & $6.03\left(\mathrm{~N}_{3} \times \mathrm{P}_{1}\right)^{*}$ & $4.67\left(\mathrm{~N}_{3} \times \mathrm{P}_{1}\right)^{*}$ & $5.26\left(\mathrm{~N}_{3} \times \mathrm{P}_{1}\right)^{*}$ & $4.52\left(\mathrm{~N}_{3} \times \mathrm{P}_{1}\right)^{*}$ \\
\hline $\mathrm{C} \times \mathrm{P}$ & $6.31\left(\mathrm{C}_{3} \times \mathrm{P}_{1}\right)^{*}$ & $5.18\left(\mathrm{C}_{3} \times \mathrm{P}_{1}\right)^{*}$ & $5.43\left(\mathrm{C}_{3} \times \mathrm{P}_{1}\right)^{*}$ & $4.82\left(\mathrm{C}_{3} \times \mathrm{P}_{1}\right)^{*}$ \\
\hline $\mathrm{N} \times \mathrm{C} \times \mathrm{P}$ & $6.73\left(\mathrm{~N}_{3} \times \mathrm{C}_{3} \times \mathrm{P}_{1}\right)^{*}$ & $5.86\left(\mathrm{~N}_{3} \times \mathrm{C}_{3} \times \mathrm{P}_{1}\right)^{*}$ & $5.91\left(\mathrm{~N}_{3} \times \mathrm{C}_{3} \times \mathrm{P}_{1}\right)^{*}$ & $5.04\left(\mathrm{~N}_{3} \times \mathrm{C}_{3} \times \mathrm{P}_{1}\right)^{*}$ \\
\hline \multirow{2}{*}{ Interactions } & \multicolumn{2}{|c|}{ RGR 145-175 days (g/g/week) } & \multicolumn{2}{|c|}{ Root fresh weight (g) } \\
\hline & $\mathbf{1}^{\text {st }}$ season & $2^{n d}$ season & $\mathbf{1}^{\text {st }}$ season & $2^{n d}$ season \\
\hline $\mathrm{N} \times \mathrm{C}$ & $0.180\left(\mathrm{~N}_{3} \times \mathrm{C}_{3}\right) *$ & $0.198\left(\mathrm{~N}_{3} \times \mathrm{C}_{3}\right) *$ & $1286\left(\mathrm{~N}_{3} \times \mathrm{C}_{3}\right) *$ & $1293\left(\mathrm{~N}_{3} \times \mathrm{C}_{3}\right) *$ \\
\hline $\mathrm{N} \times \mathrm{P}$ & $0.175\left(\mathrm{~N}_{3} \times \mathrm{P}_{1}\right) *$ & $0.201\left(\mathrm{~N}_{3} \times \mathrm{P}_{1}\right) *$ & $1248\left(\mathrm{~N}_{3} \times \mathrm{P}_{1}\right) *$ & $1267\left(\mathrm{~N}_{3} \times \mathrm{P}_{1}\right) *$ \\
\hline $\mathrm{C} \times \mathrm{P}$ & $0.171\left(\mathrm{C}_{3} \times \mathrm{P}_{1}\right)^{*}$ & $0.182\left(\mathrm{C}_{3} \times \mathrm{P}_{1}\right) *$ & $1229\left(\mathrm{C}_{3} \times \mathrm{P}_{1}\right) *$ & $1252\left(\mathrm{C}_{3} \times \mathrm{P}_{1}\right) *$ \\
\hline $\mathrm{N} \times \mathrm{C} \times \mathrm{P}$ & $0.191\left(\mathrm{~N}_{3} \times \mathrm{C}_{3} \times \mathrm{P}_{1}\right)^{*}$ & $0.215\left(\mathrm{~N}_{3} \times \mathrm{C}_{3} \times \mathrm{P}_{1}\right) *$ & $1297\left(\mathrm{~N}_{3} \times \mathrm{C}_{3} \times \mathrm{P}_{1}\right) *$ & $1365\left(\mathrm{~N}_{3} \times \mathrm{C}_{3} \times \mathrm{P}_{1}\right) *$ \\
\hline \multirow{2}{*}{ Interactions } & \multicolumn{4}{|c|}{ Sucrose Purity } \\
\hline & $\mathbf{1}^{\text {st }}$ season & $2^{n d}$ season & $1^{\text {st }}$ season & $2^{n d}$ season \\
\hline $\mathrm{N} \times \mathrm{C}$ & $17.61\left(\mathrm{~N}_{1} \times \mathrm{C}_{3}\right) *$ & $18.57\left(\mathrm{~N}_{1} \times \mathrm{C}_{3}\right) *$ & $87.89\left(\mathrm{~N}_{1} \times \mathrm{C}_{3}\right) *$ & $84.01\left(\mathrm{~N}_{1} \times \mathrm{C}_{3}\right) *$ \\
\hline $\mathrm{N} \times \mathrm{P}$ & $17.18\left(\mathrm{~N}_{1} \times \mathrm{P}_{2}\right) *$ & $18.41\left(\mathrm{~N}_{1} \times \mathrm{P}_{2}\right) *$ & $87.41\left(\mathrm{~N}_{1} \times \mathrm{P}_{1}\right) *$ & $83.48\left(\mathrm{~N}_{1} \times \mathrm{P}_{1}\right) *$ \\
\hline $\mathrm{C} \times \mathrm{P}$ & $17.47\left(\mathrm{C}_{3} \times \mathrm{P}_{2}\right) *$ & $17.74\left(\mathrm{C}_{3} \times \mathrm{P}_{1}\right) *$ & $86.14\left(\mathrm{C}_{3} \times \mathrm{P}_{2}\right) *$ & $83.55\left(\mathrm{C}_{3} \times \mathrm{P}_{2}\right) *$ \\
\hline $\mathrm{N} \times \mathrm{C} \times \mathrm{P}$ & $17.67\left(\mathrm{~N}_{1} \times \mathrm{C}_{3} \times \mathrm{P}_{1}\right) *$ & $18.52\left(\mathrm{~N}_{1} \times \mathrm{C}_{3} \times \mathrm{P}_{1}\right) *$ & $88.31\left(\mathrm{~N}_{1} \times \mathrm{C}_{3} \times \mathrm{P}_{1}\right) *$ & $84.24\left(\mathrm{~N}_{1} \times \mathrm{C}_{3} \times \mathrm{P}_{1}\right) *$ \\
\hline
\end{tabular}




\begin{tabular}{|c|c|c|c|c|}
\hline \multicolumn{5}{|c|}{ TABLE 12. Cont. } \\
\hline \multirow{2}{*}{ Interactions } & \multicolumn{2}{|c|}{ Sugar recovery $(\%)$} & \multicolumn{2}{|c|}{ Sucrose loss (\%) } \\
\hline & $\mathbf{1}^{s t}$ season & $2^{\text {nd }}$ season & $\mathbf{1}^{s t}$ season & $2^{\text {nd }}$ season \\
\hline $\mathrm{N} \times \mathrm{C}$ & $15.68\left(\mathrm{~N}_{1} \times \mathrm{C}_{2}\right) *$ & $15.47\left(\mathrm{~N}_{1} \times \mathrm{C}_{1}\right) *$ & $1.75\left(\mathrm{~N}_{3} \mathrm{x} \mathrm{C}_{1}\right) *$ & $2.35\left(\mathrm{~N}_{3} \times \mathrm{C}_{3}\right) *$ \\
\hline $\mathrm{N} \times \mathrm{P}$ & $15.48\left(\mathrm{~N}_{1} \times \mathrm{P}_{1}\right) *$ & $15.55\left(\mathrm{~N}_{1} \times \mathrm{P}_{2}\right) *$ & $1.74\left(\mathrm{~N}_{3} \times \mathrm{P}_{2}\right) *$ & $2.43\left(\mathrm{~N}_{3} \times \mathrm{P}_{1}\right)^{*}$ \\
\hline $\mathrm{C} \times \mathrm{P}$ & $15.24\left(\mathrm{C}_{2} \times \mathrm{P}_{1}\right)^{*}$ & $14.95\left(\mathrm{C}_{3} \times \mathrm{P}_{1}\right) *$ & $1.65\left(\mathrm{C}_{1} \times \mathrm{P}_{1}\right)^{\mathrm{ns}}$ & $2.31\left(\mathrm{C}_{2} \times \mathrm{P}_{1}\right) *$ \\
\hline $\mathrm{N} \times \mathrm{C} \times \mathrm{P}$ & $16.07\left(\mathrm{~N}_{1} \times \mathrm{C}_{2} \times \mathrm{P}_{1}\right) *$ & $15.83\left(\mathrm{~N}_{1} \times \mathrm{C}_{2} \times \mathrm{P}_{1}\right) *$ & $1.78\left(\mathrm{~N}_{3} \times \mathrm{C}_{2} \times \mathrm{P}_{1}\right)^{*}$ & $2.50\left(\mathrm{~N}_{3} \times \mathrm{C}_{2} \times \mathrm{P}_{1}\right)^{*}$ \\
\hline \multirow{2}{*}{ Interactions } & \multicolumn{2}{|c|}{ Root yield (ton/fed) } & \multicolumn{2}{|c|}{ Recoverable sugar yield (ton/fed) } \\
\hline & $1^{s t}$ season & $2^{n d}$ season & $1^{\text {st }}$ season & $2^{n d}$ season \\
\hline $\mathrm{N} \times \mathrm{C}$ & $40.60\left(\mathrm{~N}_{3} \times \mathrm{C}_{3}\right) *$ & $39.32\left(\mathrm{~N}_{3} \times \mathrm{C}_{3}\right) *$ & $6.07\left(\mathrm{~N}_{3} \times \mathrm{C}_{3}\right) *$ & $5.60\left(\mathrm{~N}_{3} \times \mathrm{C}_{3}\right) *$ \\
\hline $\mathrm{N} \times \mathrm{P}$ & $38.72\left(\mathrm{~N}_{3} \times \mathrm{P}_{2}\right) *$ & $38.73\left(\mathrm{~N}_{3} \times \mathrm{P}_{2}\right) *$ & $5.64\left(\mathrm{~N}_{3} \times \mathrm{P}_{2}\right) *$ & $5.45\left(\mathrm{~N}_{3} \times \mathrm{P}_{2}\right) *$ \\
\hline $\mathrm{C} \times \mathrm{P}$ & $38.58\left(\mathrm{C}_{3} \times \mathrm{P}_{2}\right) *$ & $37.92\left(\mathrm{C}_{3} \times \mathrm{P}_{2}\right) *$ & $5.98\left(\mathrm{C}_{3} \times \mathrm{P}_{2}\right) *$ & $5.68\left(\mathrm{C}_{3} \times \mathrm{P}_{2}\right) *$ \\
\hline $\mathrm{N} \times \mathrm{C} \times \mathrm{P}$ & $41.57\left(\mathrm{~N}_{3} \times \mathrm{C}_{3} \times \mathrm{P}_{2}\right) *$ & $41.02\left(\mathrm{~N}_{3} \times \mathrm{C}_{3} \mathrm{x} \mathrm{P}_{2}\right) *$ & $6.30\left(\mathrm{~N}_{3} \times \mathrm{C}_{3} \times \mathrm{P}_{2}\right) *$ & $5.87\left(\mathrm{~N}_{3} \times \mathrm{C}_{3} \times \mathrm{P}_{2}\right) *$ \\
\hline
\end{tabular}

$\begin{array}{lll}\mathrm{N}_{1}=60 \mathrm{~kg} \mathrm{~N} / \mathrm{fed} & \mathrm{C}_{1}=0 \text { ton comp. } / \mathrm{fed} & \mathrm{P}_{1}=40000 \mathrm{plant} / \mathrm{fed} \\ \mathrm{N}_{2}=80 \mathrm{~kg} \mathrm{~N} / \mathrm{fed} & \mathrm{C}_{2}=1 \text { ton comp. } / \mathrm{fed} & \mathrm{P}_{2}=46000 \mathrm{plant} / \mathrm{fed} \\ \mathrm{N}_{3}=100 \mathrm{~kg} \mathrm{~N} / \mathrm{fed} & \mathrm{C}_{3}=2 \text { ton comp. } / \mathrm{fed} & \end{array}$

$\mathrm{N}_{3}=100 \mathrm{~kg} \mathrm{~N} /$ fed $\quad \mathrm{C}_{3}=2$ ton comp. $/ \mathrm{fed}$

*Denote significant at $5 \%$ level of probability.

${ }^{\mathrm{ns}}$ Denote nonsignificant at $5 \%$ level of probability.

\section{Conclusion}

Increasing $\mathrm{N}$ rate up to $100 \mathrm{~kg} / \mathrm{fed}$ enhanced beet growth in terms of LAI, RGR and fresh and dry weight of tops and roots, but excess nitrogen depressed juice beet quality in terms of sucrose, purity and recoverable sugar percentages. Application of $100 \mathrm{~kg} \mathrm{~N}+2$ tons of compost +46000 plants/fed maximized root and sugar yields.

\section{References}

Abd El-Aal, A.M., Allam, S.M. and Besheit, S.Y. (2007) Influences of nitrogen fertilization on productivity and quality aspects of some sugar beet varieties under ElFayoum conditions. Egypt. J. Appl.Sci. 22(1),111-124.

Allam, S. A. H., Mohamed, K. E.,.El-Sayed, G. S. and Osman, A. A. M. H. (2005) Effect of sowing date, nitrogen fertilizer and row space on yield and quality of sugar beet crop. Annals of Agricultural Sciences, Moshtohor, 43(1),11-24. 
Besheit, S.Y., Mekki, B.B. and El-Sayed, M.A. (1995) Yield and technological characters of sugar beet as affected by rates and time of nitrogen application. J. Agric. Sci. Mansoura Univ. 20(1), 61-69.

Carter, J.N. and Traveller, D.J. (1981) Effect of time and amount of nitrogen uptake on sugar beet growth and yield. Agron. J. 73 (4), 665-671.

Eckhoff, J.L.A., Halvorson, A.D., Weiss, M.J. and Bergman, J.W. (1991) Seed spacing for nonthinned sugar beet production. Agron. J. 83(6), 929-932.

El-Geddawy, I.H., Osman, M.S., Abd El-Fadil, M. S. and El-Labbody, A.H.S. (2003) Effect of some agri-practices on yield and its attributes of sugar beet. Egyptian J. Agric. Res. 80(4), 1671- 1691.

El-Hennawy, H.H., Ramadan, B.S.H. and Mahmoud, E.A. (1998) Response of sugar beet to nitrogen fertilization levels and time of application. J. Agric. Sci. Mansoura Univ. 23 (3) 969-978.

El-Shafai, A.M.A. (2000) Effect of nitrogen and potassium fertilization on yield and quality of sugar beet in Sohag Governorate, Egypt. J. Agric. Res. 78 (2), 759-767.

Halverson, A. D. and Hartman, G. P. (1980) Response of several sugar beet cultivars to $\mathrm{N}$ fertilization. Yield and grown tissue production. Agron. J. 72, 664-669.

Halverson, A.S. and Hartman, G.P. (1988) Nitrogen needs of sugar beet produced with reduced tillage system. Agron. J. 80, 719-722.

Imura, E. and Hayassaka, M. (1987) Estimation of soil nitrogen fertility for sugar beet. 3-Relationship between amino-N and total nitrogen absorption. Proceedings of the Sugar Beet. Research Association Japan, No. 29, pp.127-132. Nippon beet manufacturing Co. Ltd., Obihiro 080, Japan.

Kadar, I., Petroczki, F., Hamori, V. and Morvai, B. (2009) Effect of communal sewage sludge and slaughterhouse waste compost on soil and crops in a field experiment. Agrokemia es Tolajtan, 58 (1),121-136.

Lauer, J. G. (1995) plant density and nitrogen rate effects on sugar beet yield and quality early in harvest. Agron. J. 87, 586-591.

Maareg, M. F., Gohar, I. M. A. and Tawfik, S.F. (2008) Effect of certain organic soil amendments on sugar beet (Beta vulgaris L.) infested with root-kont nematode, Meloidogyne javanica under field conditions. Egyptian Journal of Biological Pest Control,18(1), 235-241.

Mahmoud, E. A, Khalil, N. A. and Besheet, S. Y. (1990) Effect of nitrogen fertilization and plant density on sugar beet. Proc. $4^{\text {th }}$ Conf. Agron., Cairo, 15-16 Sept. (II), pp. 433-446.

Mohamed, H. Y. (2008) Influence of some biochemical fertilization regimes and organic fertilizer on yield and quality of some sugar beet varieties, Ph.D. Thesis. Fac. Agric., Zagazig Univ., Egypt. 
Montemurro, F., Maiorana, M., Convertini, G. and Ferri, D. (2007) Alternative sugar beet production using shallow tillage and municipal solid waste fertilizer. Agronomy for Sustainable Development, 27(2),129-137.

Nassar, A.M. (2001) Effect of plant density on the production of some sugar beet varieties. Agric. Sci. J. Mansoura Univ. 26 (12), 7533- 7546.

Nassar, M., El-Hovssini, A. A. and Baroum, M. S. (2000) Effect of organic manure and $\mathrm{GA}_{3}$ on fodder beet (Beta vulgaris L.) grown under saline conditions. J. Agric. Sci. Mansoura Univ. 25(8), 4865- 4876.

Prosba Biaczyk, U., Regiec, P. and Mydlarski, M. (2001) Impact of nitrogen fertilization on the technological value of sugar beet cultivar roots. Electronic J. Polish Agric. Univ., Agron. 1(4), 1-10.

Ramadan, B.S.H. (1999) Differential response of some sugar beet varieties to plant density and harvesting dates. Agric. Sci. J. Mansoura Univ. 24 (2), 413- 423.

Salama, A. M. and Badawi, M. A. (1996) Evaluation of six sugar beet cultivars under N-levels and harvesting dates. J. Agric. Sci. Mansoura Univ. 21(1),139-153.

Snedecor, G.V. and Cochran, W.G. (1967) "Statistical Methods" $6^{\text {th }}$ ed., Iowa State Univ. Press, Amess, Iowa, USA.

Steel, R.G. and Torrie, H.H. (1980) "Principles and Procedures of Statistics". $2^{\text {nd }}$ ed. McGraw Hill. New York.

Strand, P. and Vales, J. (1987) Some factors affecting the production and quality of sugar beet. Roslinna Vyroba, 33 (9), 915-924.

Watson, D.J. (1958) The dependence of net assimilation rate of leaf area index. Ann. Bot. Lond. N.S. 22, 37-54.

(Received 30/4/2012;

accepted $1 / 7 / 2012)$ 


\section{تأثير الأسمدة الآزوتية العضوية والمعدنية والكثافة النباتية على

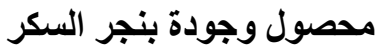

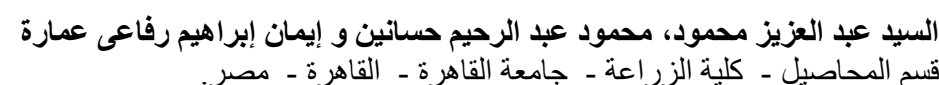

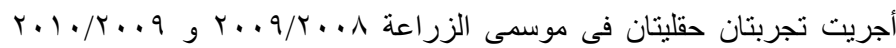

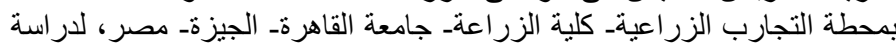

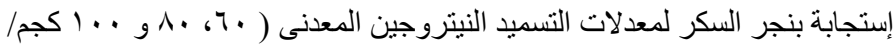

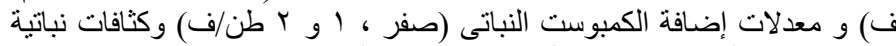

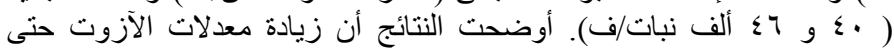

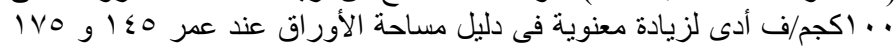

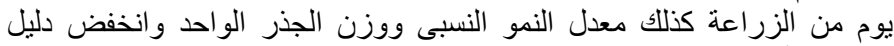

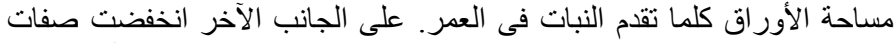

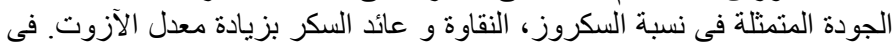

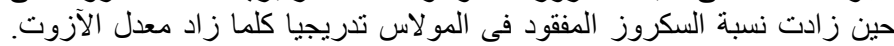

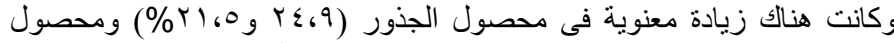

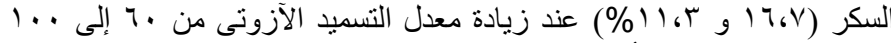
كجم ن/ف فى الموسم الأول والثاني على التو التى.

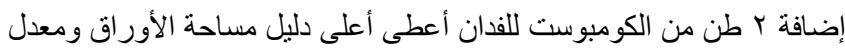

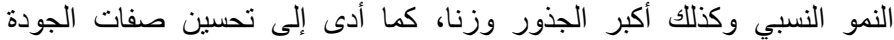

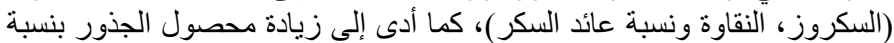

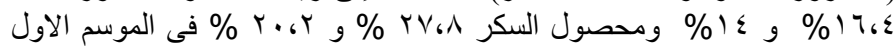
و الثانى على التو الىى.

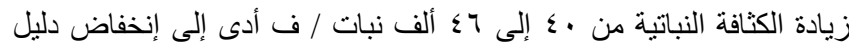

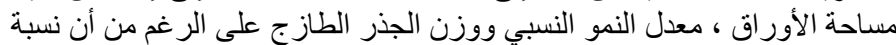

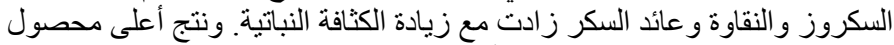

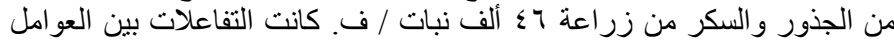

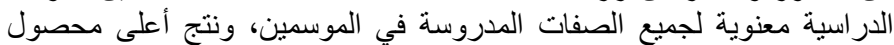

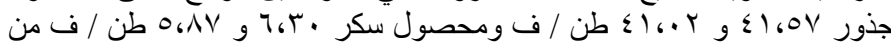

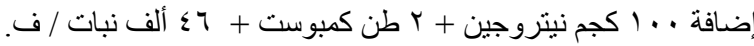

